\title{
Practical Analysis of the Combination of Enterprise Culture and Business Management
}

\author{
Huang Linna ${ }^{1}$ \\ ${ }^{1}$ Chongqing Business Vocational College, Chongqing, 400036
}

Keywords: enterprise culture; management; practice

\begin{abstract}
As the strength of enterprise development, enterprise culture can enhance the competitiveness of enterprises and strengthen the operation and management of enterprises, and plays an important role in the process of enterprise development. The longer the enterprise develops, the higher its cultural value is embedded in the enterprise. Many challenges and opportunities are faced in the development of the enterprise. In this case, the enterprise needs to combine the culture and management closely, providing a huge room for the development of the enterprise and a good working environment for employees, so as to achieve the rapid development of enterprise construction.
\end{abstract}

\section{Introduction}

With the continuous development of our economy, nowadays China has formally entered the era of knowledge-based economy and the phenomenon of enterprise competition in the development of enterprises is widespread. Corporate culture plays an important role in the competition of enterprises. Corporate culture mainly includes the cultural representatives of enterprises and the overall spirit embodied by enterprises. It is an important part of an enterprise. Corporate culture mainly refers to the company's own basic goals, behaviors, values, etc. In today's fierce market competition, companies need to combine their own culture and management, enhance the corporate culture, we can enhance the ability of enterprises to innovate, and promote Corporate culture on the development and reform of enterprises, for the development of enterprises to create a good atmosphere.

\section{The Status of Enterprise Culture and Business Management}

The management system of an enterprise has already been established at the beginning of the establishment of an enterprise. However, the management of many enterprises still adopts the traditional operation means and management mode. In the process of internal management, many employees manage the employees in the enterprise according to the traditional rules and regulations of the enterprise These unreasonable management patterns have limited the development of enterprises, thus causing the development of enterprises to stagnate. At present, many enterprises pay more attention to the effective combination of corporate culture and business management, and put forward many new entrepreneurial spirits. They want the corporate culture to manage the inside of the enterprise in the daily business activities. However, there are still many problems in the actual implementation of the combination of corporate culture and management, which are mainly reflected in the following aspects. One is the lack of a suitable carrier in the establishment of corporate culture and the other is the lack of internal managers The knowledge about the construction of enterprise culture greatly affects the prospect of the development of enterprise culture. The third is that the internal managers of the enterprise focus only on the management of the enterprise surface, thus ignoring the construction of the basic culture within the enterprise. In the process of corporate culture creation, it largely reflects the will of internal managers and neglects the idea of internal employees. Therefore, in the process of combining culture with management, enterprises need to conduct overall management and analysis of internal conditions and external conditions in accordance with the actual conditions of the development of enterprises, 
and deepen the establishment of cultural management [1].

\section{The Connotation of Enterprise Culture and the Role of Business Management}

Corporate culture mainly refers to the formation of a unique corporate business norms and business values in the occurrence of business activities. In the course of business development and management, corporate culture is the core of enterprise development. Corporate culture is to formulate corporate rules The effective system as a whole. Corporate culture is the carrier of the value of business management and management philosophy. The connotation of corporate culture mainly includes the form culture, the concept form culture and the phenomenon shape culture. The concept of form is mainly embodied in the internal culture of an enterprise, which is the hub of the development of enterprise culture. The concept of shape and culture is mainly one of the deepest cultures in the enterprise, which mainly includes the spirit of the enterprise, the development goals and the values of the enterprise. One of the basic culture within the enterprise; the phenomenon of the shape of the culture is mainly a concrete manifestation of corporate culture, mainly through the performance of products produced by enterprises, enterprises need to be based on the characteristics of their own development, building a reasonable culture [2].

Corporate culture on the role of enterprise management: Corporate culture is an important product of the process of enterprise development is the key to the development of an enterprise, the smooth development of a business depends on the internal cultural development. Corporate culture not only promote the role of business management, but also have a guiding role for employees within the enterprise, corporate culture can unify the thinking of employees, unified business philosophy. Corporate culture can also regulate corporate behavior, the correct constraints of employees regulate their own behavior, establish a good corporate image, the deep cultural connotation of the enterprise into the minds of employees. [2] A profound corporate culture can establish a good working environment for employees and guide employees to actively participate in the internal activities and management of enterprises and contribute to the development of the enterprise. Strengthening the building of enterprise culture can promote the all-round development of the enterprise, strengthen the construction of the internal cultural system of the enterprise, and re-educate the employees of the enterprise. In the business management, fully embodies the humane enterprise system, so that employees feel the internal enterprise management system [3]. Corporate culture combined with business management, a good institutional culture to care for employees, motivate staff, mobilize the enthusiasm of staff in the work, corporate culture combined with the management process to fully consider the immediate interests of employees and the development of enterprises, the establishment of a science. Reasonable corporate culture system, at the same time, strengthen the construction of enterprise knowledge and culture, provide the cultural quality of enterprise managers, strengthen the internal study of enterprises, strengthen the employees' professional ethics education and professional knowledge and skill training activities, and create a good atmosphere for learning while still needing strengthen the education of employees, improve the overall quality and cultural level of employees, introduce corresponding competition in the process of normal learning, guide employees actively, motivate employees to re-learn interest, let each employee conscientiously implement the work and strictly abide by the work. Professional ethics, providing employees with the overall ability and cultural level. In the business management and cultural development of long-term integration of planning, purposeful, step-by-step, establish a scientific and basic system of corporate culture.

\section{Enterprise Culture in the Establishment of Business Management}

The establishment of enterprise culture requires enterprises to conduct continuous and long-term work. The scope of enterprise culture is broad. The main contents are material culture, institutional culture, behavioral culture and spiritual culture. 


\subsection{Material culture}

Enterprise's material culture is mainly reflected in the company's trademark, advertising, hardware and staff's overall image, etc., the material culture of enterprises can directly reflect the working atmosphere within an enterprise. The establishment of corporate material culture, mainly to standardize the work of various departments within the enterprise, the design of a unified corporate logo image, business badges, flags, etc., but also in the enterprise procurement unified office logo and equipment, unified advertising specifications, due to staff. To a large extent, the image represents the overall image of the enterprise. Therefore, it is also important to standardize the work of uniforms and words and deeds. At the same time, a great deal of publicity should be carried out to expand the brand awareness of enterprises and set up a large number of publicity columns and sections, enhance the contagious power among the internal personnel of the enterprise; at the same time, the material culture is also reflected in the establishment of certain cultural facilities and public entertainment projects within the enterprise measures to create a good internal corporate culture [4].

\subsection{Institutional culture}

The reasonable operation within the enterprise can not be separated from the effective system. In the enterprise, we should formulate a reasonable system according to the current situation and development capability of the enterprise. The system mainly includes the personnel system, the staff examination system, the labor system and the reasonable distribution system, In the enterprise to establish an effective management model and standardize the work flow, enhance the management ability of enterprises and staff self-restraint, at the same time in the enterprise implementation of "people-oriented" management philosophy, and constantly innovate the system of enterprises and improve business productivity, To promote the development of enterprises.

\subsection{Behavior culture}

Corporate behavior culture embodies the image of the enterprise, corporate culture of behavior mainly includes the exchange of enterprises, social behavior and behavior of production and business activities. In the process of business activities, we must first determine the staff code of conduct, and then resolutely enforced, while strengthening the training of internal staff, so that employees in strict accordance with the guidelines set by the internal work. Strengthen the publicity and promotion of personal deeds of outstanding employees of enterprises, promote typical people and things, let other employees of the enterprise learn from excellent employees, and fully reflect the internal culture of the enterprise from outstanding employees. While establishing a good style of corporate behavior, Establish a good corporate image.

\subsection{Spiritual culture}

The spirit of enterprise culture is mainly reflected in the spirit of enterprise, the overall corporate values and corporate slogans, corporate spirit and culture is mainly to explore the spirit of the internal content of enterprises, internal condensation of the core forces to form a group of sound corporate workforce, reflected business values. Enterprises in the development process, to a certain standard, we should attach importance to the core concepts of enterprises, the core concepts can be based on the status of enterprises and enterprises involved in the scope of the building, the core concept of the enterprise written written text, and then all staff to learn, so that all employees understand the reasonable concept of business, work together for the development of corporate culture infusion of a spiritual force [5].

\section{The Combination of Enterprise Culture and Business Management}

The core of the combination of enterprise culture and business management is mainly to improve the overall quality and management level of internal employees and enterprise management. If you want to realize the all-round development of an enterprise, we must strengthen the building of the internal culture of the enterprise, mainly from the spirit, system, behavior and material aspects of 
the implementation of a unified, while completing the overall strategy for the internal development of enterprises to improve the overall competitiveness of enterprises, and strengthen the management of enterprises, to create endowment with the spirit of cultural connotation of corporate philosophy and corporate values. Build a unique corporate culture, strengthen the building of internal culture, establish an evaluation mechanism of internal science and a perfect system so that under the scientific operation and management of the enterprise, the overall image of the enterprise and the scientific management level of the enterprise can be fully improved Good corporate culture. In the process of building corporate culture, we need to develop an effective system to regulate the long-term development of enterprises, to ensure the construction of corporate culture has a certain continuity [6]. For the effective combination of corporate culture and business management, we must establish a complete corporate culture building system, starting from the behavioral, spiritual, material and institutional culture, and build a complete culture based on the actual business activities in the enterprise. Construction system, at the same time the actual cultural system into the overall establishment of the enterprise plan for the operation and management of enterprises to provide effective guidance. In the process of combining the management of business activities and the corporate culture, it is necessary to comprehensively enhance the basic quality of employees, strengthen the training of employees, popularize the internal values and promote the management philosophy within the enterprise, and at the same time, formulate reasonable corporate rules. And enterprise system, in the process of establishing practice, establish a good corporate image, deepen the internal cultural construction.

\section{Conclusion}

After entering the economic era, competition between enterprises intensified each other, the competition between enterprises is actually the competition between the corporate culture, corporate culture is a comprehensive embodiment of the enterprise, which reflects the corporate culture, the enterprise Productivity slowly translates into material productivity. An enterprise in the course of many years of development, rich cultural heritage, in today's fierce market environment, you want to achieve leaps and bounds of the enterprise, it is necessary to combine business management and corporate culture, cultural management of the enterprise.It is necessary to reform and innovate the original culture, cultivate a new enterprise culture, comprehensively promote the enterprise development strategy, manage the enterprise with the enterprise culture, create a good environment for the enterprise and promote the long-term development of the enterprise.

\section{References}

[1] Xie Jing, Zhang Binjie. A Practical Study on the Fusion of Corporate Culture and Business Management - Taking "Home" Culture Construction of Jiangsu Petroleum as an Example [J]. Journal of Petrochemical Industry and Management College, 2016,18 (2): $34-38$.

[2] Liu Ying. Analysis of the impact of corporate culture on the operation and development of modern enterprises [J]. Value Engineering, 2014, (4): 186-187.

[3] Jin Wenhua. The Impact of Corporate Culture on Transnational Management of Chinese Enterprises [J]. Science and Technology Information, 2014, (3): 252,287.

[4] Zeng Wenli. Analysis of the application of corporate culture in the management of production and operation [J]. Contemporary Economy, 2016, (17): 30-31.

[5] Deng Yan. Exploration of the integration of business management and corporate culture [J]. Science and Technology, 2014, (33): 20-21.

[6] Xie Haiyan. Analysis of the role of corporate culture in business management [J]. Science and Wealth, 2015, (11): 546-546. 